\title{
Book Review: Madness and Civilization: A History of Insanity in the Age of Reason
}

\author{
Yue Wang \\ Department of German, Nanjing Normal University, Wenyuan Street 1, Nanjing, China
}

\begin{abstract}
This article briefly describes the main content and artistic value of the book Madness and Civilization: A History of Insanity in the Age of Reason, providing people with a new angle of reading and thinking.
\end{abstract}

Keywords: madness, reason, an archaeological approach.

\begin{abstract}
Madness and Civilization: A History of Insanity in the Age of Reason shows madness, which is feared, distorted, manifested and judged by reason. It tries to prove that "madness" is not a natural phenomenon, but a product of civilization[1]. The author, Michel Foucault, one of the most important philosophers, thinkers and historians of the 20th century, was born in 1926 and died in 1984.
\end{abstract}

The book, first published in 1961, was Foucault's doctoral dissertation at the University of Paris. It is a philosophical work. It is analytical, comprehensive and critical. It divides the history of madness into three main periods: the late Middle Ages to the Renaissance, the classical period and the modern period, in which Foucault critiqued enlightenment, reason, institutional mechanisms and psychiatry through the changes of fate of madness.

The book begins with a chapter called "Ship of Fools." Despite the disappearance of leprosy at the end of the Middle Ages, the hospitals used to exclude and isolate leprosy patients survived. By the Renaissance had the poor, the convict, and the 'deranged' taken the place of the leper. Then, the author tells how mad people were driven out by the "ship of fools". They were driven out in boats, forced to wander, forgotten and ostracized. As expulsion became a custom, madness also caught the attention of society. But at that time, the attitude towards madness was ambiguous, it was seen both as a threat and as a means of reaching the truth[2]. Many creators of literature and art thought that madness was revelatory and expressed their true thoughts in this way. Just as the author said: "Madness is no longer an alien feature of the world as we know it. It is an ordinary landscape, a feature of the times."

The second chapter is called "The Great Confinement." It points out that in the classical period madness was silenced by a special kind of coercion. This coercion was the building of places for confinement, where the poor, the unemployed, the prisoners and the mad were kept together. During this time, madness was understood socially in terms of poverty, inability to work and inability to integrate with groups. It was seen as a destructive force and a threat to society and the rule of reason. As a result, people used confinement to bind the madman, which was seen as physical and moral bondage. With the confinement of the madman, madness became a sin, suppressed, isolated, and rejected by civilization.

In the following chapters, time passes to the modern period.
The birth of mental hospitals in the 19th century marked a new era of madness. Madness was no longer regarded as a sin, but was treated as a mental illness. Foucault focuses on the analysis of the mental hospital established by Tuke and Pinel. Tuke believed that religion was a cure for madness, while Pinel believed that religion stimulated and caused madness. He chose to place justice and the moral structures of order in his mental hospital. Both treatments used unusual means of monitoring and judging the patient, erasing their qualities of being "human" in order to distort and control madness more firmly[3]. In the mental hospital, the doctor was the incarnation of judicial and moral guarantee, had absolute authority over the mental patients, and drove the rational to conquer the irrational with the help of scientific power. At this point, madness was not only driven out of the space of civilization, but also compulsively controlled by reason, losing the right to speak freely.

As a critic of reason, Foucault did not discuss the history of madness from the point of view of reason, nor did he give a clear definition of madness, because he refused to regard madness as an unchangeable reality, which is not a thing but a function[4]. In this book, he regarded madness as a carrier of rational authority. By tracing the origins of a series of social systems and analysing social consciousness, he distinguished all kinds of rational presuppositions, which were attached to the concept of madness or constituted the consciousness of madness, in order to grasp the formation process of rational authority by means of deconstruction. This way of interpretation is undoubtedly of positive significance to the reflection of rationality and modernity[5]. But, as Derrida notes, there is a flaw in the book. It wants to tell the history of madness itself without reason, that is, to let madness speak for itself, but the author used the language of reason to describe the history of madness, which is contradictory. As soon as we begin to write about the madman, we have involuntarily placed ourselves in a different camp. It is therefore impossible to tell the history of madness in such a language[6].

Even so, the book is a perfect philosophical work. Foucault used an archaeological approach to study the communication and relationship between madness and reason in the course of history and criticized enlightenment, reason, institutional mechanisms and psychiatry. Besides, he provided a new research perspective and a new research method, and gave examples, which are meaningful. 


\section{References}

[1] Ping Yuan. Degenerated Reason and Suppression Madness - An Interpretation of Madness and Civilization. Cultural and educational information, 2020(07): 43-44+68.

[2] Huang Hui. Madness Silence and Rational Monologue An Interpretation of Foucault's Madness and Civilization. French Studies, 2010(01): 47-53.

[3] Qin Xinghua. Rereading Foucault's Madness and Civilization - A History of Madness in the Age of Reason - Also on the Irrationality in Art. Wide Angle of art, 2018(03): 83-89.

[4] Mo Weimin. Fate of the subject. Shanghai: SDX Joint Publishing Company, 1999.

[5] Huang Hui. Madness Silence and Rational Monologue An Interpretation of Foucault's Madness and Civilization. French Studies, 2010(01): 47-53.

[6] Guo Shuobo. Silent "Ship of Fools" - An Interpretation of Foucault's Madness and Civilization. Beauty and the Times (II), 2011(11): 23-27. 